\title{
Gejala Alienasi dalam Masyarakat Konsumeristik \\ Oleh
}

\section{Aditya Permana ${ }^{1}$}

\begin{abstract}
Abstrak
Masyarakat konsumer adalah masyarakat yang telah mengalami transformasi dari mode of production yang mencirikan kapitalisme lama ala Marx ke mode of consumption yang menandai era kapitalisme baru. Kapitalisme baru mengonstruksi masyarakat yang mengartikulasikan diri dalam objek-objek konsumsi yang menjadikan individu sekedar etalase tanda agar kemelimpahan produksi komoditi terus berjalan dan pemilik modal terus menangguk untung. Kapitalisme baru mereifikasi petanda-petanda (signifiers) komoditi dan melipatnya dalam kebutuhan-kebutuhan palsu (pseudo-needs) yang dijadikan 'norma sosial' baru yang berlandaskan pada konsumsi. Berkat kemajuan teknologi dan sistem konsumsi baru, kapitalisme baru menemukan solusi untuk mengatasi masalah alienasi buruh dalam mode of production. Namun konsumerisme sebagai efek langsung mode of consumption justru melahirkan alienasi yang jauh lebih luas dan tersamar. Tulisan ini mengangkat topik tersebut melalui kacamata pemikir sosial-filsafat postmodern, Jean Baudrillard.
\end{abstract}

Kata kunci: konsumsi, masyarakat konsumer, konsumerisme, reifikasi, alienasi.

\begin{abstract}
The consumer society is name for a society that transformed from mode of production, as the prominent feature of old capitalism criticized by Marx, to mode of consumption that marks a new era of capitalism, or so-called late capitalism. This new capitalism constructs a society which articulates itself into objects of consumption. Individuals in this system become a mere storefront of signs and significations, manipulated by owners of the capital in order to keep the commodification and capital's flow in the determinate manners, via method of reification of commodities. This method creates pseudo-needs which consumed conspicuously by society and become a new "social norm". New capitalism relies on the technological upturn and the new system of consumption to solve the problem of alienation grappled by workers in Marx's mode of production. But, unfortunately, mode of consumption operated by new capitalism brings forth consumptive behavior which in turn, set a new disguised problem of alienation. To discuss this problem, I will employ Baudrillardian perspective.
\end{abstract}

Keywords: consumption, consumer society, consumerism, reification, alienation.

\section{A. Pendahuluan}

Begitu Apple meluncurkan iPhone 5 September lalu, ratusan penggila produk ini rela antri berjam-jam untuk memperoleh gadget idaman mereka. Di kalangan anak muda, memiliki Blackberry seakan menjadi suatu syarat diterimanya seorang individu dalam peer group-nya. Komputer tablet menjadi penanda status dan identitas. Di luar gadgets, kita juga dibuat terpukau pada kalangan sosialita yang kerap berganti-ganti tas bermerk yang sangat

\footnotetext{
${ }^{1}$ Aditya Permana menyelesaikan studi sarjana S1 di Filsafat Universitas Gadjah Mada pada tahun 2009. Sedang Menempuh S2 Filsafat di STF Driyakarya Jakarta. Penulis menaruh minat pada kajian filsafat, teori sosial dan linguistik.
} 
mahal, senilai sebuah mobil niaga, hanya untuk alasan eksis dalam pergaulan. Terlalu banyak contoh untuk ini. Fakta sosial ini, konsumerisme, sudah menjadi hal yang sangat umum. Menurut Prof. Franz Magnis- Suseno, bangsa kita menghadapi ancaman dari dua sudut, yakni konsumerisme yang latah mengikuti segala macam globalisasi. Tantangan yang kedua adalah ekstrimisme dan kepicikan agamis, demikian kata Romo Magnis dalam Dialog Budaya Nusantara yang digelar Gerakan Fajar Nusantara di Jakarta, Kamis 12 Januari 2012 (Suseno, 2012).

Konsumerisme di Indonesia dipicu oleh peningkatan taraf perekonomian dan imbas globalisasi. Globalisasi menjadikan konsumerisme sebagai suatu aktivitas sosial yang tidak lagi sekadar melibatkan, meminjam bahasa Marx, nilai-guna suatu barang (objek). Objek dikonsumsi bukan semata-mata karena kemampuannya memenuhi kebutuhan dasar. Kebanyakan pemilik gadgets ini selain kelas eksekutif atau pegawai kantor yang membutuhkan gadget yang andal dan portabel tanpa menghilangkan konektivitas mereka dengan kolega, gadgets tersebut juga dimiliki anak- anak muda yang memanfaatkan gadgets tersebut sebagai peranti mengakses social media. Sebuah perangkat komputer tablet atau smartphone tersebut dibeli bukan karena gadgets tersebut memiliki fungsi sebagai alat yang memudahkan pekerjaan, melainkan karena tablet itu menjadi penanda sosial, penanda kelas, pembeda kelas, yang ditandai oleh difungsikannya alat tersebut sebagai piranti "bergaul" dan mengekspresikan identitas.

Masyarakat menjadi apa yang disebut Jean Baudrillard (1929-2007) sebagai "masyarakat konsumer". Menurut Baudrillard, manusia telah mengalami perubahan fundamental mengenai cara pandang mereka terhadap orang lain. Manusia tidak dilihat sebagai manusia sebagaimana adanya, melainkan direduksi menjadi kumpulan objek:

"Kini, kita dikepung oleh konsumsi dan kemakmuran yang sangat menyolok dimanamana, yang terbentuk oleh pelipat-gandaan objek, jasa, dan benda-benda material. Halhal ini kini membentuk mutasi fundamental dalam ekologi spesies manusia. Kasarnya, orang-orang makmur tidak lagi dikelilingi oleh manusia-manusia lain, sebagaimana mereka dilihat di masa lalu, melainkan (dikelilingi) oleh objek-objek." (Baudrillard, 1998).

Tatanan masyarakat menjadi sistem objek-objek (system of objects). Dalam masyarakat konsumer, fungsi objek konsumsi menjadi semakin kompleks. Jenis dan tata nilai yang ditawarkan pun semakin beragam. Selain itu siklus serta tempo pergantian komoditi semakin pendek dan cepat. Siklus tersebut dipengaruhi oleh trend, kemelimpahruahan, kebosanan, serta keborosan. Paling tidak hal tersebut tampak jelas pada kelas masyarakat yang mempunyai budaya konsumsi berlebihan (conspicuous consumption) seperti selebriti, kaum jetset, remaja kelas menengah ke atas di perkotaan yang telah mencapai tahap belanja gaya hidup (lifestyle shopping) (Piliang, 2003). Masyarakat konsumer membeli sesuatu dan membelanjakan uang lebih berdasarkan kepada prestise dan kebanggaan simbolik, bukan pada fungsi (nilaiguna). Inilah "ideologi" yang kini semakin 
transparan berlangsung dalam aktivitas konsumsi masyarakat kapitalistik dewasa ini. Nilai-tanda (sign-value) dan nilai-simbol (symbolic-value) telah menggantikan nilai-guna (use-value) dan nilai-tukar (exchange-value) Marxian. Kapitalisme baru memerlukan bentuk-bentuk konsentrasi ekonomi baru, teknik-teknik produksi baru, pengembangan teknologi baru, percepatan kapasitas produkproduk massal dan korporasi kapitalis, sehingga meningkatkan perhatian terhadap pengaturan konsumsi dan menciptakan kebutuhan-kebutuhan baru atas dasar kuasa simbolik tanda. Baudrillard menyebutnya rezim nilai-tanda (Baudrillard, 1981).

Namun kesenjangan sosial belum lenyap. Jika gaya hidup menjadi standar bagi relasi antar-manusia, maka orang yang tidak memiliki atau tidak mampu menerapkan gaya hidup konsumtif dalam masyarakat konsumer menjadi pihak yang tersingkir. Akibatnya perbedaan dan pembedaan "kelas-kelas" sosial makin cair, namun secara ironik juga semakin tajam. Ketika konsumsi menjadi ukuran diterimanya seseorang dalam kelas tertentu, maka muncul masalah-masalah sosial seperti totalitarianisme, hilangnya makna, anomie, penyakit jiwa, alienasi, dan sebagainya.(Hardiman, 1993). Secara langsung maupun tidak langsung ini juga menyuburkan kriminalitas demi tujuan-tujuan banal: asosiasi kepada identitas tertentu, yang hanya dapat diperoleh melalui kepemilikan atas objekobjek atau produk-produk yang disebut di atas. Inilah hebatnya, konsumerisme bukan hanya menjangkiti kelas menengah ke atas, melainkan menerpa hampir seluruh kelas yang mengalamatkan identitas diri pada rezim ekonomi simbolik. Berdasarkan latar belakang tersebut, tulisan ini akan memfokuskan diri pada topik masyarakat konsumer dalam kaitannya dengan permasalahan alienasi antar kelas sosial berdasarkan ukuran ekonomi yang tidak didasarkan pada nilai-guna, melainkan ekonomi nilai-tanda dan nilai-simbol melalui kacamata pemikir sosial Jean Baudrillard.

\section{B. Teori Konsumsi Baudrillard}

Jean Baudrillard sering dianggap sebagai pemikir garda depan yang mengkaji persoalan masyarakat konsumer secara cukup komprehensif karena tidak saja mengkritik filsafat ekonomi politik Marx, melainkan memasukkan problem ini dalam linguistik struktural rintisan Saussure dan semiologi Barthes. Baudrillard menyimpulkan bahwa konsumsi dewasa ini bukanlah konsumsi atas objekobjek material, melainkan konsumsi akan nilai-nilai; konsumsi atas tanda (signs). Baudrillard memulai diskusi tentang masyarakat konsumer dengan diagnosisnya akan rezim nilai-tanda. Rezim nilaitanda adalah "ideologi" yang dihidupi oleh masyarakat yang menjalankan logika sosial konsumsi. Dalam rezim nilai-tanda, motif terakhir tindakan konsumsi bukanlah pelayanan dan nilaiguna suatu barang, melainkan produksi dan manipulasi penanda-penanda sosial. Konsumsi menjadi motif utama dan penggerak realitas sosial, buday, dan bahkan politik (Kellner, 1994). Rezim nilai-tanda ditandai oleh transformasi dari mode of production ke mode of consumption. Nilai-tanda (sign-value) dan nilai-simbol (symbolic-value) telah menggantikan nilai-guna (use-value) dan nilai-tukar (exchange-value) Marxian. Konsumsi menjadikan seluruh aspek kehidupan tak lebih sebagai sekedar objek yang mengklasifikasi dan membentuk makna kehidupan masyarakat kapitalisme lanjut. 
Baudrillard mengatakan bahwa ketika sebuah produk dikonsumsi, yang dikonsumsi adalah makna-makna yang disebarluaskan melalui iklan (Baudrillard, 2002). Melalui asumsi ini, Baudrillard hendak menjelaskan tentang kemelimpahan (profusion) tanda-tanda yang menyebar luas. Relasi antara tanda dan konsumsi merupakan poin penting memahami relasi baru antara subjek-objek dalam masyarakat konsumer (Baudrillard, 2002).

Baudrillard melihat bahwa dalam masyarakat konsumer, objek-objek dimiliki, diatur, dikonsumsi, dan diinvestasi melalui makna oleh subjek yang kemudian mengubah dan mendefinisikan ulang objek- objek tersebut. Baudrillard percaya bahwa konsumsi objek-objek menentukan tatanan sosial masyarakat. Dengan mengadaptasi teori strukturalis, Baudrillard berargumen adanya relasi timbal-balik antara individu dan sistem makna dalam masyarakat. Sistem makna memaksakan kekuasaannya terhadap individu dengan cara bahwa melalui sistem makna tersebutlah individualitas mendapat makna (William, 2002). Logika sosial konsumsi memuat dua aspek. Pertama, sebagai proses signifikansi dan komunikasi yang didasarkan pada peraturan (code) di mana praktik-praktik konsumsi masuk dan mengambil makna. Konsumsi dalam konteks ini merupakan sistem pertukaran yang sepadan dengan sistem bahasa. Kedua, sebagai proses klasifikasi dan diferensiasi sosial. Objekobjek dan tanda-tanda dipandang bukan hanya sebagai perbedaan yang signifikan dalam satu kode, melainkan sebagai nilai yang sesuai aturan dalam sebuah hierarki. Konsumsi menentukan distribusi nilai yang melebihi hubungannya dengan penanda sosial yang lain, seperti pengetahuan, kekuasaan, budaya, dan lain-lain. (Baudrillard, 1998)

\begin{abstract}
"Objek-objek konsumsi menciptakan pembedaan sebagai stratifikasi status: apabila hal ini tidak lagi terisolasi, hal ini terdiferensiasi; apabila hal ini menentukan secara kolektif para konsumen sebuah tempat dalam relasi kode, tanpa melebihi solidaritas kolektif (justru berlawanan dengan itu." (Baudrillard, 1998)
\end{abstract}

Baudrillard menjelaskan bagaimana nilai-tanda dan nilai-simbol ini dapat menjadi basis relasi subjekobjek dan tatanan sosial yang baru dalam masyarakat post-feodal. Akan lebih mudah untuk memahami transisi masyarakat konsumer dengan membandingkan masyarakat feodal dan masyarakat kapitalis (Baudrillard, 1981). Menurut Marx, masyarakat feodal memproduksi dan mengonsumsi objek menurut nilai-gunanya, yakni fungsi asli suatu objek berdasarkan eksistensinya. Barang-barang diproduksi atau dipertukarkan dengan alasan pemenuhan kebutuhan. Namun memasuki zaman industrialisasi, perekonomian ditandai dengan lahirnya sistem baru yang disebut kapitalisme. Dalam kapitalisme, muncul konsep mengenai nilaitukar di samping nilai-guna yang telah dikenal sebelumnya. Logika produksi yang mendominasi era kapitalisme akhirnya memunculkan konsep komoditi. Komoditi adalah objek produksi yang di dalamnya memuat dua nilai dasar, yakni nilai-guna dan nilai-tukar.

Namun produksi komoditi menyingkirkan nilaiguna sebagai nilai dominan yang menjadi prinsip interaksi sosial, ekonomi, budaya dan politik dalam masyarakat feodal. Dalam masyarakat kapitalis, pemenuhan kebutuhan bukan merupakan motif 
utama produksi barang-barang. Produksi komoditi menekankan pada nilai-tukar untuk mendapatkan selisih keuntungan dari biaya yang dikeluarkan untuk produksi. Dengan konsep komoditi, barang yang memiliki manfaat berbeda, tidak mustahil memiliki nilai-tukar yang sama (Lechte, 1994) Satu ton gabah misalnya, mungkin memiliki nilai-tukar yang sama dengan sebuah mobil, meskipun keduanya memiliki perbedaan nilai-guna. Konsep komodifikasi mengubah status uang sebagai alat tukar. Marx menyatakan, apabila dalam era kapitalisme awal uang hanyalah sarana tukar pemenuhan kebutuhan, maka dalam era kapitalisme lanjut uang adalah tujuan akhir dengan komoditi sebagai sarananya (Kellner, 1994). Sebuah komoditi tanpa nilai-guna berarti tidak dapat dijual karena tidak memiliki nilai-tukar. Benda tersebut akan menjadi produksi tak berguna. Namun sebaliknya, tidak setiap produk yang memiliki nilai-guna otomatis akan memiliki nilai-tukar. Nilai fetish suatu komoditi akan muncul ketika komoditi itu dipertukarkan dalam sistem kapitalisme. Karakter fetish tersebut didefinisikan Marx sebagai relasi sosial tertentu antara manusia yang tampak bagi mereka, merupakan bentuk fantasi, dari relasi antara benda (komoditi-komoditi) (Marx, 1976).

\section{Alienasi dan Konsumsi dalam Masyarakat Kapitalistik Lama (Old Capitalism)}

Pada era kapitalisme awal, masyarakat ditandai oleh logika produksi yang berprinsip pada produksi komoditi yang melimpah (mode of production). Produksi komoditi menegaskan kemenangan nilaitukar atas nilai-guna, atau fetisisme komoditi. Dalam fetisisme komoditi terjadi alienasi terhadap kaum buruh sebagai produsen. Kaum buruh teralienasi karena pertama, komoditi dipisahkan dari produsennya. Kaum buruh sebagai orang-orang yang memproduksi komoditi tidak memiliki kekuasaan untuk memiliki atau menggunakan komoditi tersebut sesuai keinginan mereka karena komoditi menjadi milik pemilik kapital yang kemudian dipertukarkan di pasar untuk mendapatkan keuntungan. Untuk memiliki barang yang diproduksinya sendiri, kaum buruh harus mengeluarkan uang untuk membeli barang tersebut. Kaum buruh menjadi konsumen atas produk yang mereka produksi sendiri; teralienasi dari produk kerjanya. Yang kedua, kaum buruh sebagai konsumen juga teralienasi akibat hilangnya akses yang bermakna terhadap sarana-sarana produksi yang diperlukan untuk menggali sepenuhnya potensi kebutuhan mereka sebagai manusia (Lee, 2006).

Marx melihat sumber problem ini pada proses reifikasi dalam komodifikasi benda-benda produksi. Reifikasi menggambarkan relasi sosial kaum buruh dalam kapitalisme yang tumbuh di luar kontrol dan muncul sebagai sesuatu yang digerakkan oleh hukum "natural" sehingga kaum buruh seakan dikendalikan oleh logika dari luar diri mereka (Lee, 
2006). Hukum "natural" ini tak lain adalah sistem kapitalisme.

Bagi kaum buruh, tak ada jalan lain selain menyesuaikan diri dengan sistem kapitalisme, meskipun ini merepresi dan mendistorsi kualitas esensial mereka sebagai manusia. Di lain pihak, bekerja atau menjadi buruh sesungguhnya merupakan realisasi potensi mereka sebagai mahluk yang bebas dan sadar. Barang yang mereka produksi tak lain adalah bentuk objektivikasi kualitas esensial manusiawi mereka.

Maka, reifikasi tak lain adalah alienasi. Gartman mengklaim reifikasi sebagai proses alienasi dalam bentuk penghilangan kesadaran atau pembiusan terhadap nalar kritis manusia yang bertujuan untuk pelupaan asal usul mode produksi yang memiliki sifat represif dan dehumanistis. Kaum buruh dipaksa menerima kondisi mereka sebagai pekerjapekerja yang bergantung kepada kapitalisme untuk menjamin mereka mendapat penghasilan untuk memenuhi kebutuhan hidup sehari-hari. Kaum buruh mau tidak mau harus menerima represi tersebut sebagai suatu keadaan tak terelakkan yang tetap harus berlangsung untuk menjamin tersedianya penghasilan. Karena itulah sistem kapitalisme justru harus terus berjalan dan dilanggengkan (Gartman, 1986).

Menurut Marx, reifikasi sebagai alienasi ini terjadi dalam dua aspek yang dihidupi kaum buruh yaitu dalam pasar dan dalam tempat kerja. Reifikasi dalam pasar erat kaitannya dengan fetisisme komoditi atau pengistimewaan nilai-tukar atas nilai-guna. Dalam pasar, komoditi dipertemukan dan dipertukarkan berdasarkan kekuatan bawah sadar yang mengatasi kontrol manusia atas pasar. Kekuatan ini merupakan kekuatan yang berada di balik relasi benda-benda sebagai hasil pengaburan (obscurity) nilai-guna; produsen memproduksi barang yang telah diabstraksi nilai-gunanya sehingga menjadi komoditi yang bernilai-tukar murni secara melimpah dan dengan itu menciptakan berbagai macam kebutuhan palsu untuk dikonsumsi sebagai barang-barang konsumsi par excellence. Dalam komoditi, nilai-nilai, termasuk di dalamnya tenaga buruh, dipertukarkan dan diabstraksi sehingga bernilai sama dengan nilai tukar yang menentukan harga komoditi. Sedangkan reifikasi dalam tempat kerja yang mengalienasi kaum buruh terjadi manakala mereka kehilangan kontrol atas diri mereka karena telah "menyerahkan hak" sebagai manusia yang bebas dan mampu merealisasikan natur esensialnya di bawah kontrol kapitalisme. Potensi kaum buruh diabstraksi tak lebih dari sekedar nilai-lebih (surplus value), direduksi sampai taraf abstrak dan sederhana sebagai biaya energi (expenditure of energy) yang dapat dihitung dan dimanipulasi secara kuantitatif oleh modal. Relasi antar manusia tampak bukan sebagai sebuah alam komunal, melainkan relasi abstrak antara bendabenda yang diatur oleh hukum kuantitatif yang oleh kapitalisme berhasil ditransendensikan sebagai hukum alam (Gartman, 1986).

Seturut perubahan zaman, melalui modernisasi dan optimalisasi teknologi, kaum buruh tidak lagi tersingkir. Produksi komoditi yang melimpah menempatkan baik kaum buruh maupun konsumen sebagai kelas konsumen pasif karena kemelimpahan komoditi berimbas pada murahnya harga barang. Ini adalah pergeseran kapitalisme dalam bentuknya yang baru. Tidak ada lagi kelangkaan yang mengharuskan setiap orang memproduksi barang 
untuk memenuhi kebutuhan. Yang ada justru kebutuhan-kebutuhan palsu (pseudo-needs) yang sengaja dimunculkan untuk menjamin tetap berputarnya mekanisme produksi.Kebutuhankebutuhan palsu muncul sebagai akibat kemenangan konsep nilai-tukar di atas nilai-guna. Konsep nilai-tukar telah merelatifkan distingsi antara kebutuhan 'nyata' dan 'palsu'. Baudrillard yakin bahwa seluruh kebutuhan sesungguhnya selalu diciptakan secara sosial. Dalam teori fetisisme komoditi, komoditi diproduksi bukan semata-mata untuk pemenuhan nilai-guna suatu objek. Lebih dari itu, komoditi diberi nilai-nilai baru yang seringkali jauh dari nilai-gunanya.

Karena itu Baudrillard mengatakan bahwa distingsi konsep nilai-guna dan nilai-tukar sudah tidak memadai lagi untuk menjelaskan teori kebutuhankebutuhan palsu dalam kerangka masyarakat yang telah beranjak meninggalkan logika produksi menuju logika sosial konsumsi, atau acap disebut sebagai masyarakat kapitalisme lanjut (late capitalism). Masyarakat telah bergeser dari fase perkembangan kapitalisme dimana bentukkomoditas bersifat dominan ke fase kelazimankelaziman bentuk-tanda (Lury, 1998). Konsumsi, dipahami bukan dalam kerangka nilai-guna sebagai guna material, melainkan dengan nilai-tanda sebagai signifikansi. Komoditi mendapat makna dari operasi kode-kode simbolis. Makna komoditi tercipta atau tepatnya, diciptakan, melalui merk (brand) tetapi tidak dipahami dalam kaitannya dengan sifat intrinsik (nilai-guna) suatu barang, melainkan dalam pengertian ekonomi. Aspek pertama dari logika sosial konsumsi, yaitu sebagai proses signifikansi dan komunikasi yang didasarkan pada peraturan (code) dimana praktik-praktik konsumsi masuk dan mengambil makna terpenuhi dalam pengertian ini. Kebutuhan-kebutuhan palsu menandakan sosialitas masyarakat konsumer yang tidak lagi membutuhkan partisipasi universal dalam produksi. Namun logika ini hanya mensyaratkan setiap orang untuk memainkan peran signifikansi (Lury, 1998).

\section{Situasi Masyarakat Kapitalisme Baru atau Masyarakat Konsumer}

Baudrillard banyak mengambil ide Debord tentang "masyarakat tontonan" (society of spectacle) untuk menjelaskan kemenangan logika komoditi. Komoditi adalah suatu bentuk tontonan (spectacle), dengan mengganti yang real dengan citaan-citraan. Fetisisme komoditi mencapai pemenuhan puncaknya dalam tontonan, dimana dunia real digantikan oleh citraan-citraan yang dipilih yang direproduksi di atasnya, yang secara simultan berhasil membuat dirinya menjadi epitomi (ringkasan/padatan) realitas. Apa yang disaksikan dan yang ada adalah dunia komoditi yang mendominasi seluruh pengalaman hidup. Debord sepakat dengan Marx bahwa fetisisme komoditi merupakan suatu bentuk pengasingan (estrangement) manusia satu sama lain dan dari benda-benda yang mereka produksi (Debord, 1967) Menurut Debord, tontonan adalah suatu panggung ketika komoditi berhasil mengkolonialisasi kehidupan sosial secara menyeluruh. Komodifikasi tidak sekedar tampak, namun justru kita tidak dapat melihat apapun karena apa yang kita lihat sesungguhnya adalah dunia komoditi. Ruang sosial diselimuti lapisan-lapisan komoditi yang 
mengelompokkan massa dalam fragmen-fragmen yang terputus dari operasi produksi. Debord menyamakan proses yang terjadi dalam "logika produksi" dengan apa yang terjadi di "logika konsumsi". Akibat pengidentikan ini, massa menjadikan konsumsi yang teralienasi (alienatedconsumption) serupa "tugas" massa sebagaimana alienasi yang sama terjadi dalam produksi (Debord, 1967). Apabila produksi mengalienasi kaum buruh, konsumsi mengalienasi konsumen dengan cara yang sama.

Alienasi dalam masyarakat tontonan terjadi karena citraan-citraan (images) direpresentasikan oleh komoditi mempengaruhi massa sebagai suatu kehidupan sosial. Proses ini terjadi secara bawahsadar dan menjadi cerminan individu dalam berperilaku. Semakin individu mengkontemplasikan diri atau memproyeksi diri dalam objek-objek yang merefleksikan "kebutuhan", semakin ia mengidentifikasi diri dengan imaji-imaji tersebut. Akibatnya ia semakin jauh dari dirinya sendiri. Individu tidak mampu memahai hidup dan keinginannya sendiri. Tindakan dan perilaku (gesture) subjek tidak lagi merefleksikan dirinya sendiri, melainkan gesture orang lain yang direpresentasikan melalui dirinya (Debord, 1967). Baudrillard menyimpulkan bahwa kapitalisme dengan logika konsumsinya berhasil menciptakan kebutuhan-kebutuhan palsu yang kemudian ditindaklanjuti dengan pemenuhan kebutuhankebutuhan tersebut dalam dunia signifikansi. Akibatnya individu kehilangan kontrol atas otonomi diri dan 'menyerah' pada kode dan aturan-aturan signifikansi. Bagi Baudrillard, inilah perwujudan aspek kedua dari logika sosial konsumsi yaitu sebagai proses klasifikasi dan diferensiasi sosial.
Menurutnya, orang-orang tidak lagi menggunakan objek untuk mengekspresikan diferensi antara mereka, melainkan manusia sekedar menjadi 'kendaraan'untuk mengekspresikan perbedaan di antara objek-objek (Lury, 1998).

Ini terjadi akibat simulasi dalam peristiwa atau produk-produk. Produk-produk tersebut tidak memiliki makna yang jelas dan tidak mengacu pada referensi apaupun kecuali sekedar menunjukkan diferensi objek, namun tanpa memuat makna atau pesan apapun. Menyitir McLuhan, medium telah menjadi pesan itu sendiri. Makna atau pesan bukan hal yang penting dalam mekanisme simulasi. Justru histeria realitas-realitas semu yang muncul akibat proses simulasi tersebutlah yang penting. Baudrillard menyatakan bahwa masyarakat telah memasuki dunia hiperealitas. Dalam dunia hipereal, apabila yang real itu diproduksi, yang hipereal itu direproduksi (Bertens, 1995). Simulasi juga merupakan bentuk masyarakat tontonan (Baudrillard, 2006). Secara hiperbolik Baudrillard mengatakan bahwa semua yang nyata kini menjadi simulasi (Baudrillard, 1994).

Simulakrum adalah dunia yang terbentuk dari hubungan berbagai nilai, fakta, tanda dan kode secara acak, tanpa referensi relasional yang jelas, atau suatu duplikasi dari realitas dengan menggunakan reproduksi ikonik realitas. Hubungan ini melibatkan tanda real (fakta) yang tercipta melalui proses produksi, serta tanda semu (citra) yang tercipta melalui proses reproduksi. Dalam dunia simulasi, kedua jenis tanda tersebut saling tumpang tindih, melarut, dan bersengkarut membentuk satu unitas. Mana yang asli, yang real, dan mana yang palsu, yang semu, sukar diidentifikasi. Semuanya menjadi bagian realitas 
yang dijalani dan dihidupi. Realitas tidak lagi memiliki referensi, kecuali simulakrum itu sendiri (sebagai referennya) (Baudrillard, 1994). Realitas kini dapat dibuat, direkayasa. Realitas dapat disimulasi. Dalam simulasi, seluruh referensi dihilangkan, dibuat persamaan dalam model oposisi biner dan kombinasi aljabar dalam teknologi informasi. Akan tetapi yang dihasilkan dari proses itu bukan imitasi, reduplikasi, atau parodi, melainkan suatu penggantian realitas dengan tandarealitas. Baudrillard mengalegorikannya dengan "metafora simulasi": "citraan tidak dapat lagi merepresentasikan realitas, karena ia sendiri real. Mimpi pun tidak ada lagi, karena ia adalah realitas virtual (virtual reality). Citraan berubah menjadi realitas virtual karena telah kehilangan kekuatan untuk merepresentasikan realitas" (Baudrillard, 1993). Citraan menjadi sesuatu yang lebih nyata dari yang nyata, lebih dari real dari yang real: hipereal (hyperreal).

Konsumsi luar biasa atas tanda ini menandakan kerterpisahan manusia dari refleksi atau perpektif tentang dirinya sendiri. Manusia dalam masyarakat konsumer tidak lagi dihadapkan pada citranya demi yang terbaik atau terburuk. Yang ada hanya sekedar "etalase", tempat geometris konsumsi, dimana individu tidak merenungkan dirinya sendiri, melainkan terserap dalam kontemplasi objek-objek atau tanda-tanda yang berlipat ganda; terserap dalam tatanan penanda status sosial dan lain-lain. Individu tidak lagi memikirkan dirinya sendiri. Ia telah terserap dan terhapus melalui dan dalam permainan tanda dan lembaga kode. Baudrillard menegaskan, subjek konsumsi adalah susunan tanda-tanda (Baudrillard, 1998) Masyarakat konsumer menemukan pemenuhan-dirinya dalam arus tanda- tanda dan simulakrum. Sebagai konsumer, manusia menjadi soliter, seluler (terpencar seperti sel-sel), dan senang berkerumun (gregarious),misalnyamenyaksikan televisi bersama keluarga, menyaksikan pertandingan olahraga di stadion, konser musik, kafe, atau bioskop (Baudrillard, 2002).

Baudrillard menyetarakan proses alienasi yang terjadi dalam masyarakat konsumer dengan proses alienasi dalam mode produksi yang bermuara pada proses reifikasi dan fetisisme komoditi (Baudrillard, 2002) Kapitalisme dituduh melakukan penghancuran referensi atau tujuan manusia dengan cara menghancurkan distingsi ideal antara benar-salah maupun baik-buruk, dengan tujuan membangun hukum radikal persamaan dan pertukaran. Dengan ini realitas semu disuntikkan dimana-mana untuk meyakinkan masyarakat tentang realitas sosial, ekonomi, dan finalitas produksi (Baudrillard, 2002). Dengan kata lain realitas dan referensi perlu direkayasa, dimanipulasi, atau bahkan dihancurkan agar rezim konsumsi tetap berdiri. Dengan cara ini, masyarakat berusaha merestorasi/memulihkan "yang real" untuk melarikan diri dari "histeria" produksi dan reproduksi realitas yang menggantikan realitas sesungguhnya. Masyarakat mencari solusinya dari produksi dan reproduksi. Namun kekuasaan kapital hanya menyediakan material-material produksi yang berifat hipereal. Tidak ada yang diproduksi selain tanda (Baudrillard, 2002).

Baudrillard menegaskan bahwa proses signifikasi (penandaan) tak lebih dari suatu model raksasa simulasi makna (gigantic simulation model of meaning). Baudrillard menolak ide Derrida tentang proses signifikasi yang selalu mengimplikasikan 
realitas konkret yang memuat "idealisme referensi" (Baudrillard, 2002). Dalam simulasi tidak ada referensi. Arbitraritas tanda yang krusial dalam semiologi Sausurrean, Barthes, atau Derrida tidak lagi dapat dipertahankan. Konsep nilai-tanda Baudrillard mendasarkan diri pada reduksi dan penangkapan tanda dalam simulakrum. Konsekuensinya, tanda menjadi sesuatu yang menyesatkan karena ia menjadikan dirinya terlihat sebagai sebuah totalitas, menghapus jejak-jejak transendensi abstraknya (genealoginya dari referensi atau realitas), dan merayakan diri sebagai prinsip kesejatian dari makna (reality principle of meaning) (Baudrillard, 2002) Semua makna dispektakulerkan, digambarkan, dirangsang, diolah, diaransemen dengan gambar-gambar, tanda-tanda, dengan contoh-contoh yang bisa dikonsumsi (Baudrillard, 1998). Tanda-tanda pengganti realitas tersebut mengambil tempat dalam sistem objek yang diorganisasikan aturan-aturan trend dan fungsi-fungsi imperatif (memiliki kemampuan untuk memerintah atau mendorong) dan menjalankan prinsip "integrasi ideologis": subjek menjadi "seseorang" (person) melalui proses personalisasi yang diatur dan diarahkan oleh sistem tanda objek. Individu menemukan makna diri, identitas, dan "diri sejatinya" ketika ia berhadapan vis-à-vis objek: imaji atau tanda (Pawlett, 2008). Singkatnya, manusia direduksi sebagai susunan tanda.

Piliang (2003) berpendapat bahwa Baudrillard sebenarnya menganggap alienasi dan dehumanisasi barisan pekerja dalam proses produksi komoditi sudah tidak lagi relevan. Ia juga menambahkan bahwa masalah alienasi tersebut telah teratasi dalam model produksi simulasi melalui otomatisasi, komputerisasi, dan mikroisasi. Namun itu hanya dapat dipahami jika merujuk pada model produksi komoditi klasik. Piliang tidak mengeksplorasi lebih jauh soal alienasi dalam masyarakat konsumer, melainkan hanya mengungkapkan soal fetisisme komoditi yang sama sekali lain dengan fetisisme komoditi-nya Marx yang menjadikan alienasi tidak lain adalah alienasi terhadap nilai-tukar atau penanda dalam sistem rantai pertandaan. Dalam konteks rantai pertandaan, Baudrillard menilai fetisisme komoditi Marx tak lain adalah fetisisme petanda (nilai-guna). Nilai-guna dipisahkan atau dialienasikan dari komoditi sehingga komoditi tersebut hanya tampak sebagai objek sarat nilai yang sebenarnya palsu. Yang ditampakkan adalah permainan tanda-tanda yang diinstitusionalisasi untuk menopengi kepentingan ideologis kapitalis atas nilai-tukar.

Baudrillard menolak asumsi Marx dan mengatakan fetisisme komoditi, jika memang benar ada, tak lain adalah fetisisme nilai-tukar atau penanda dari suatu objek. Fetisisme nilai-tukar memiliki makna terperangkapnya subjek dalam kode-kode objek yang dikodifikasi secara sistematis melalui sistem kapitalisme. Dengan kata lain, fetisisme komoditi berlaku pada objek tanda atau objek sebagai tanda akibat pemutusan atau pemisahan nilai-guna sebagai nilai substansial objek sehingga menjadi objek yang sepenuhnya berupa nilai-tanda (Piliang, 2003). Berdasarkan argumen ini, Piliang dan Baudrillard sendiri menyimpulkan bahwa diskusi soal alienasi tidak lagi bermanfaat dalam debat tentang komoditi dalam masyarakat konsumer. Akan tetapi soal alienasi lebih bernilai krusial apabila menyangkut "manusia" dalam proses alienasi dari komoditi atau fetisisme komoditi 
tersebut. Piliang memang menyebutkan alienasi sebagai pemutusan barisan pekerja dari komoditi yang mereka produksi, namun Piliang menerima begitu saja bahwa alienasi kaum buruh sudah berakhir dengan berlangsungnya model produksi simulasi.

\section{E. Otopsi Konsep Alienasi dalam Pemikiran} Baudrillard

Dalam teori fetisisme komoditi, alienasi menimpa kaum buruh yang dipisahkan dari komoditi yang mereka produksi. Dan oleh karena cara kerja mode produksi itu sendiri, kaum buruh teralienasi juga dari sesama kaum buruh. Schacht menambahkan bahwa dengan ini kaum buruh juga teralienasi dari dirinya sendiri. Sebagai homo laborans, pekerjaan merupakan hidup seseorang, sedangkan komoditi adalah hidup yang terobjektivikasi dalam bentuk material. Ketika seseorang dialienasi pekerjaan dan produk, maka ia juga akan teralienasi dari dirinya sendiri (Schaht, 1970). Namun dalam masyarakat konsumer, masalah ini dianggap selesai. Pergeseran dari mode produksi ke mode konsumsi membuat alienasi dalam produksi komoditi menjadi tidak relevan. Kaum buruh, melalui konsumsi, dapat memiliki komoditi dengan cara konsumsi. Dengan modernisasi dan optimalisasi teknologi, kapitalis menancapkan kontrolnya lebih kuat terhadap semua lapisan sosial. Kaum buruh telah menjadi

2 Tanda, dalam perspektif strukturalisme Sausurrean dimengerti sebagai kesatuan tak terpisah antara penanda (signifier/le signifiant) dan petanda (signified/le signifie). Penanda adalah konsep material dari bahasa, yaitu apa yang ditulis, dibaca, dikatakan, atau didengar. Dalam bahasa Perancis, le signifiant berarti bunyi atau coretan yang kelas baru yang makmur. Marcuse mengindikasikan hal ini sebagai adanya masyarakat tanpa kelas.

"Jika pekerja dan atasannya menikmati program televisi yang sama dan pergi ke tempat tamasya yang sama pula, jika juru ketik merias diri semenarik anak perempuan majikannya, jika seorang kulit hitam memiliki mobil Cadillac, jika mereka semua membaca koran yang sama, maka asimilasi ini tidak hanya mengindikasikan sirnanya kelas, namun sejauh ini kebutuhan dan pemenuhan yang menjaga mapannya tatanan ini dimiliki bersama oleh seluruh masyarakat" (Marcuse, 1964).

Dalam sistem tanda, alienasi berpangkal pada teori reifikasi. Fetisisme komoditi, sebagai dasar reifikasi menyelubungi asal-usul (origin) komoditi yang dikonsumsi masyarakat. Nilai-guna dan barisan pekerja yang memproduksi komoditi disamarkan dan disembunyikan dalam kemewahan komoditi. Proses reifikasi merupakan proses pelupaan (oblivion) atas asal-usul komoditi. Konsep ini diambil Baudrillard dan ia kombinasikan dengan semiologi Barthesian. Fetisisme komoditi adalah suatu proses fetisasi terhadap penanda (signifier) serta reifikasi terhadap petanda (signified). ${ }^{2}$ Komoditi menekankan aspek nilai-tanda sebagai topeng dari objek faktual (penanda) dengan

bermakna. Sedangkan petanda adalah konsep material dari bahasa yang mewakili konsep atau makna suatu tanda. Dalam pemakaian bahasa sebagai sistem, antara penanda dan petanda tidak mewakili suatu hubungan yang natural, melainkan arbitrer (manasuka). Tidak ada hubungan natural antara huruf "a" dengan bunyi yang ditunjukkan huruf itu. 
permainan petanda yang jauh dari nilai-guna objek tersebut (referensi/referent).

Pandangan Baudrillard tentang ideologi merupakan kritik terhadap konsep ideologi sebagai "representasi palsu" yang diungkapkan Marx. Representasi palsu, menurut Marx, adalah representasi yang di dalamnya terjadi penyembunyian keterputusan (estrangement) subjek dari objek yang ia produksi, serta keterputusan nilai-guna dari nilai-tukar. Nilai-guna teralienasi karena dipandang tak lebih sebagai petanda yang dilekatkan pada objek komoditi sebagai nilai-tukar komoditi tersebut. Namun bagi Baudrillard, ideologi sudah ada pada tingkat denotasi, yaitu substansi materi dari penanda. Ideologi sudah ada pada setiap tingkat proses signifikasi (penandaan); pada tingkat penanda sekaligus petanda. Pada dasarnya, ideologi adalah proses reduksi dan abstraksi material simbolis kepada suatu bentuk. Proses ini disebabkan oleh dua hal: pertama, logika komoditi dan ekonomi politik merupakan jantung dari tanda yang terdapat dalam kesejajaran petanda dan penanda, dalam perbedaan kombinasi tanda-tanda, yang di dalamnya tanda berfungsi sebagai nilai-tukar dan nilai-guna. Kedua, struktur tanda adalah jantung dari bentuk komoditi, bahwa komoditi dengan segera menangkap efek pertandaan (signifikasi); namun bukan oleh ekses yang ditimbulkannya sebagai pesan atau konotasi, tetapi disebabkan bentuknya sendiri menjadikannya suatu media total, suatu sistem komunikasi yang mengatur semua pertukaran sosial (social exchange). Seperti halnya bentuk tanda, komoditi adalah sebuah kode yang mengatur pertukaran nilai-nilai. Tak ada perbedaan apakah yang terlibat dalam rantai signifikasi atau kandungan imaterial dari penandaan tersebut diikutkan, adalah kode sebagai determinannya: aturan permainan petanda dan nilai-tukar (Baudrillard, 1981). Dengan hal tersebut Baudrillard memproklamasikan bahwa konsep alienasi tidak lagi relevan dalam analisis ideologi masyarakat konsumer. Namun alienasi tetap dapat terjadi di level esensi manusia itu sendiri. Hal ini tampak dalam karya-karya Baudrillard pada periode simulasinya.

\section{F. Alienasi sebagai Reifikasi atas Petanda (Signifier)}

Konsep reifikasi Marx dipandang sudah tidak lagi memadai untuk menganalisis struktur budaya masyarakat konsumer. Elaborasi teori Marxis telah dilakukan Mahzab Frankfurt di satu pihak, dan pemikir semiologi-Marxis di pihak lain. Elaborasi dari Adorno, Horkheimer, dan Marcuse relatif berhasil menjelaskan bahwa reifikasi yang berlaku dalam mode konsumsi dapat dijabarkan dengan logika yang sama sebagaimana mode produksi. Abstraksi, kuantifikasi, dan manipulasi yang menjadi ciri mode produksi dapat diterapkan pula pada mode konsumsi. Akan tetapi ketiganya tidak bisa menunjukkan dengan terang bagaimana atau mengapa reproduksi atas logika produksi dapat berlaku juga dalam mode konsumsi. Di lain pihak, Barthes dan Baudrillard mencoba mengisi celah yang ditinggalkan Marx dengan memanfaatkan metode semiologi. 
Baik Barthes maupun Baudrillard memandang bahwa dalam strukturalisme, tatanan simbolis tidak hanya berfungsi sebagai media ekspresi yang netral bagi makna yang telah terbentuk dan menunggu untuk dimaterialkan dalam bahasa dan kebudayaan. Melalui teori mitologinya, Barthes memperluas analisis reifikasi pada benda-benda material. Menurut Barthes, mitos merupakan suatu bentuk karakteristik penandaan (signification) kaum borjuis. Tanda-tanda dari sistem semiologis memasuki sistem lainnya yang melepaskan kaum borjuis dari makna orisinal tanda. Bentuk mengalienasi isi dan dikembangkan untuk tujuan tertentu sehingga terjadi pembalikan, bukan makna tanda sebagai hasil proses sosial dan sejarah, melainkan sebaliknya. Barthes menanggapi asumsi Marx bahwa produsen bertindak dan membuat sejarah mereka sendiri dengan menyusun atau mengkonstitusi penandaan atas tanda sesuai kepentingan mereka sendiri. Akan tetapi dalam mitos, relasi tanda dengan kaum buruh digantikan dan dikaburkan maknanya dengan citraan- citraan alam (image of nature). Barthes menyatakan:

"Apa yang disediakan oleh dunia untuk mitos adalah realitas historis, kendatipun ini berjalan mundur sementara waktu, dengan cara di mana manusia telah memproduksi atau menggunakannya; dan apa yang mitos berikan sebagai pengembalian adalah citraan natural realitas ini...mitos disusun berdasarkan lepasnya kualitas historis benda-benda: di dalamnya, benda-benda kehilangan memori yang pernah mereka buat" (Barthes, 1972).
Barthes mengembangkan dua tingkat sistem signifikasi, yakni sistem denotasi sebagai sistem signifikasi tingkat pertama dan sistem konotasi sebagai signifikansi tingkat kedua. Sistem denotasi terdiri atas rantai penanda dan petanda, yakni hubungan konsep material dan mental dibalik suatu tanda. Sedangkan dalam sistem konotasi, rantai penanda dan petanda dalam sistem denotasi bergeser menjadi penanda. Dan hal ini terus berantai sampai berkaitan dengan petanda lain pada rantai signifikasi yang lebih tinggi. Barthes kemudian menganalisis sistem-sistem makna yang merefleksikan kode kultural masyarakat kapitalis. Objek-objek yang telah diasingkan nilai-gunanya dimasuki makna-makna sosial. Akan tetapi maknamakna sosial ini bukan diinjeksikan oleh masyarakat atau pengguna objek tersebut, melainkan justru dilakukan oleh sebagian kecil kaum borjuis (desainer, insinyur, sosialita) yang menciptakan makna-makna tertentu suatu objek konsumsi. Barthes menyebut ini sebagai ideologi. Ideologi merupakan sistem gagasan, ide, atau kepercayaan yang menjadi konvensi dan mapan dalam suatu masyarakat, yang mengartikulasikan dirinya pada sistem representasi, atau sistem signifikasi (Piliang, 2003).

Ideologi seharusnya merupakan pondasi dari sistem signifikasi. Akan tetapi dalam kultur masyarakat konsumer, ideologi sudah tidak bersifat eksplisit (denotatif). Makna denotatif berarti penyajian kode yang makna tandanya segera tampak ke permukaan berdasarkan relasi penanda dan petandanya. Dalam aspek politik ekonomi kapitalis, makna ini sudah bergeser ke tingkat konotatif. Makna konotatif kodekode dihadirkan secara implisit dan memuat maknamakna tersembunyi. Makna-makna tersembunyi 
inilah yang merupakan kawasan mitologi atau ideologi. Dalam ideologi, pergeseran status objek ke nilai-tanda murni berarti menempatkan ideologi dalam rantai kedua sistem signifikasi. Makna sosial yang dilekatkan pada suatu objek oleh sebagian kecil borjuis tersebut menggeser makna denotasi ke makna konotasi. Ideologi berubah seiring berubahnya penanda dan tidak dapat lagi menjadi pondasi proses signifikasi.

Barthes setuju dengan George Lukacs bahwa kultur borjuis dirembesi oleh bentuk-bentuk reifikasi; relasi manusia dilihat sebagai sistem benda yang diatur dan dijalankan oleh hukum-hukum yang berada di luar kontrol manusia. Barthes mencontohkan fenomena reifikasi dalam level semantis ini dengan mobil Citroen D.S. 1955; sebuah mobil manis yang aerodinamis, sebuah objek "magis". Mobil ini dikonsumsi bukan karena nilaigunanya, melainkan citra yang dilekatkan padanya. Inisial D.S. sebagai tipe mobil ini kependekan dari "Deesse" - Kesaksian Dewi, untuk menggambarkan secara superlatif desainnya yang seolah-olah berasal dari surga. Dengan ini Citroen D.S. bagaikan benda persembahan dari surga yang diantarkan oleh Dewidewi. Faktanya, "surga" tempat diproduksinya mobil tersebut sebenarnya adalah pabrik di mana kaum buruh membentuk karakter manis dan aerodinamis sang Citroen. Pendeknya, Citroen D.S. 1955 adalah suatu objek yang direifikasi, mengaburkan dan menyembunyikan fakta kaum buruh yang memproduksinya. Hal ini juga berlaku bagi komoditi-komoditi lain (Gartman, 1986).

Baudrillard melihat keterkaitan antara tanda-tanda dan sistem politik ekonomi kapitalis dalam masyarakat konsumer beserta ideologi yang melandasinya. Ia mengatakan bahwa makna ideologis dan konotasi sudah ada pada tingkat penanda dari komoditi. Ia menyebut fenomena ini sebagai fetisisme tanda. Fetisisme tanda tidak memuja makna ideologis petanda (yang seharusnya denotatif dan eksplisit), melainkan diferensi tandatanda yang disebabkan oleh pergantian dari satu penanda (bentuk, gaya) ke penanda-penanda lainnya (Piliang, 2003) Fetisasi ini menyembunyikan makna asli suatu objek dan menampakkan karakternya sebagai objek pemujaan (fetish) di level petanda. Komoditi dikonsumsi sebagai tanda-tanda di mana penanda telah diabstraksikan dari petanda atau isinya. Dengan kata lain, terjadi fetisasi terhadap penanda (signifier) serta reifikasi terhadap petanda (signified). Analogi ini digunakan Baudrillard yang mengklaim bahwa teori fetisisme komoditi Marx memiliki kekurangan pada struktur semiologis.

Kapitalisme memproduksi makna dan difference (pembedaan makna-makna objek) yang telah dimanipulasi. Apabila dibandingkan dengan teori komoditi Marx, nilai tukar ekonomis (harga) ekivalen dengan penanda (signifier) atau bentuk objek. Sedangkan nilai-guna ekivalen dengan petanda (signified) yang berupa makna artifisial yang dilekatkan pada objek. Konsumsi adalah muara di mana komoditi diproduksi sebagai tanda-tanda. Dalam struktur sosial masyarakat konsumer, konsumsi ini menentukan status sosial seseorang. Yang dikonsumsi adalah tanda; konsumsi adalah konsumsi tanda. Objek hanya sekedar memiliki arti sebagai penanda atau medium relasi tersebut. Proses ideologisasi ini atau dalam bahasa Baudrillard naturalisasi (naturalization), sudah tidak dapat dimengerti sebagi relasi infrastruktursuperstruktur antara produksi material (sistem dan 
relasi produksi) dan produksi tanda (kebudayaan, gaya hidup) yang mengekspresikan dan menopengi kontradiksi dasarnya.

Seperti telah dibahas, produksi komoditi menekankan aspek nilai-tanda sebagai wujud topeng dari objek faktual (penanda) dengan permainan petanda yang jauh dari nilai-guna objek tersebut (referensi/referent). Dorongan terhadap objek fetish dalam masyarakat konsumer bukan berasal pada objek-objek itu sendiri, melainkan pada the passion for the code (hasrat akan kode). The passion for the code merupakan artikulasi fundamental dari proses ideologis atas generalisasi seluruh level kode struktural., bukan proyeksi dari alienated consciousness (kesadaran yang teralienasi). Baudrillard menambahkan bahwa ideologi bukanlah "penipuan kesadaran" secara misterius melainkan suatu logika sosial yang digantikan dengan yang lain (kode-kode signifikasi), kemudian mengubah definisi nilai (Baudrillard, 2001). Ini membawa sistem nilai-tanda dalam arus semiosis tak terbatas yang berlangsung tanpa referensi objek dalam konsumsi. Tidak ada lagi proses petanda sebagai dasar legitimasi penanda atau sebaliknya. Akibatnya proses penandaan (signifikasi) menjadi suatu reifikasi.

"Signifikasi, merupakan juga reifikasi- semua strategi represif dan reduktif sudah hadir dalam logika internal tanda, sebagaimana halnya nilai-tukar dan ekonomi politik. Hanya revolusi total, teoritis dan praktis, yang dapat mengembalikan yang simbolik dengan pematian tanda dan nilai. Bahkan tanda-tanda harus dimusnahkan" (Baudrillard, 2002).
Sebagaimana reifikasi dalam konteks mode produksi adalah sebagai proses penghilangan kesadaran tentang asal-usul komoditi (kaum buruh yang memproduksi dan nilai-guna komoditi) yang membuat objek muncul dan benar-benar diatur oleh sesuatu di luar kendali manusia, dalam reifikasi petanda juga berlaku logika demikian. Fetisisme penanda menggeser status penanda tak ubahnya sebagai petanda. Konsep mental objek yang diwakili petanda (atau dalam konteks produksi adalah nilaiguna) mengalami distorsi atau pemutusan ketika penanda (konsep material) objek mengalami fetisasi. Fetisasi penanda menjadikan nilai-tukar bergeser pada nilai-tanda murni. Fetisasi komoditi memutuskan objek dari nilai-guna sehingga nilaitukar mendominasi pertukaran. Baudrillard melangkah lebih jauh dari Marx, fetisasi penanda memutuskan nilai-tukar murni suatu objek dan menggantikannya dengan nilai-tanda murni sehingga akhirnya yang tersisa dari objek konsumsi hanyalah tanda-tanda yang dikonsumsi sebagai sarana diferensi sosial. 


\section{G. Kesimpulan}

Proses reifikasi petanda menyebabkan individu diatur oleh logika di luar logika struktural signifikasi. Konsumsi objek dikendalikan oleh logika simulasi, dimana objek tanda dikonsumsi secara banal. Petanda menjadi tidak penting. Konsep mental dari objek itu tidak penting. Yang penting adalah banalitas penanda, yang justru diterima sebagai realitas itu sendiri. Orang mengkonsumsi iPhone 5, Blackberry, komputer tablet, tas Prada, Birkin, Louis Vuitton, mobil Ferrari, Alphard, motor besar, dan seterusnya tanpa melihat barang-barang itu sebagai benda pakai. Orang mengkonsumsi produk atau komoditi tersebut untuk menempatkan dirinya dalam status sosial tertentu melalui penanda-penanda atau makna-makna semu yang ditanamkan dalam sepatu tersebut. Mereka mengkonsumsi banalitas tanda yang disimulasi oleh komoditi tersebut tanpa menyadari barisan buruh di China dan Meksiko yang memproduksi komoditi tersebut. Mereka tidak menyadari bahwa sebuah Blackberry yang mereka beli harganya sama dengan upah satu bulan buruh-buruh itu. Dalam kasus konsumsi komoditi tersebut, reifikasi (dalam pengertian produksi) terjadi dalam aspek tidak disadarinya keberadaan kaum buruh yang memproduksi komoditi itu. Reifikasi kedua terjadi dalam level penanda. Komoditi tersebut dikonsumsi bukan sebagai benda pakai an sich, melainkan sebagai penanda status sosial seseorang di masyarakat, yang dengan itu subjek tidak menyadari bahwa ia dikendalikan oleh logika dalam sistemsistem objek yang menempatkan subjek pembeli produk-produk tersebut tak ubahnya sebagai etalase atau kendaraan bagi penanda-penanda yang dilekatkan dalam produk-produk tersebut.

\section{Daftar Pustaka}

Baudrillard, Jean. 1981. For a Critique of the Political Economy of the Sign. St. Louis, Mo: Telos Press Ltd.

-1993. Symbolic Exchange and Death. London: SAGE Publications. - 1994. Simulacra and Simulation. Michigan: University of Michigan Press. 1998. The Consumer Society: Myths and Structures. London-Thousand Oaks-New Delhi: SAGE Publications.

-2006. Ekstasi Komunikasi (diterjemahkan oleh Jimmy Firdaus). Jogjakarta: Kreasi Wacana.

Barthes, Roland. 1972. Mythologies. New York: The Noonday Press, Farrar, Straus \& Giroux.

Bertens, Hans. 1995. The Idea of Postmodern, A History. London and New York: Routledge.

Debord, Guy. 1967. The Society of Spectacle. New York: Zone Books.

Gartman, David. 1986. "Reification of Consumer Product: A General History Illustrated By The Case of the American Automobile". Sociological Theory, Vol. 4, No. 2, (Autumn, 1986): 167-185.

Hardiman, F.Budi. 1993. Kritik Ideologi: Pertautan Pengetahuan dan Kepentingan. Yogyakarta: Kanisius

Kellner, Douglas. 1994. Baudrillard Reader. Cambridge: Blackwell.

Lechte, John. 1994. Fifty Key Contemporary Thinkers, From Structuralism to Postmodernism. London: Routledge.

Lee, Martyn J. 2006. Budaya Konsumen Terlahir Kembali, Arah Baru Modernitas dalam Kajian Modal Konsumsi dan Kebudayaan (diterjemahan oleh Nurhadi). Yogyakarta: Kreasi Wacana.

Lury, Celia, 1998. Budaya Konsumen (Terjemahan Hasti T. Champion). Jakarta: Yayasan Obor Indonesia.

Magnis-Suseno, Franz. "Konsumerisme dan Ekstrimisme Ancam Masa Depan Kebangsaan Indonesia." Artikel online http://www.rimanews.com/read/2012011 3/51459/magnis-suseno-konsumerismedan-ekstrimisme-ancam-masa-depankebangsaan-indonesia

Marcuse, Herbert 1964. One-Dimensional Man, Studies in the Ideology of Advanced Industrial Society. London-New York: Routledge.

Marx, Karl.1976. Capital, Vol. I. London: Penguin Books. 
Jurnal Pemikiran Sosiologi Volume 1 No. 2, 2012

Gejala Alienasi dalam Masyarakat Konsumeristik

Aditya Permana

Pawlett, William.2008. "Against Banality - The Object System, the Sign System and the Consumption System", International Journal of Baudrillard Studies, Volume 5, Number 1 January. Laman online http://www.ubishops.ca/BaudrillardStudie s/ vol5_1/v5-1-article13-Pawlett.html

Schacht, Richard. 1970. Alienation. New York: Anchor Books. 